\title{
Gas chromatographic-mass spectrometric (GC-MS) identification of compounds in concentrates of Puerto Rican rums'
}

\author{
Heriberto Batiz' and Carmen L. Cacho
}

\begin{abstract}
A procedure is described for the improved identification of compounds in rums. It includes the preparation of rum concentrates using a Kuderna concentrator (KC), and the profiles of the resultant products using a gas chromatographic (GC) system, where the separation with a packed column is compared with that of a capillary column. The packed column was connected in the chromatograph to the flame ionization defector (FID) whereas the capillary column was interfaced, in the same chromatograph, with the mass spectrometry (MS) probe. These fechniques assessed simultaneously, provided alternative methods for compound profiles, one using the capillary column only for identification purpose with the GC-MS, and the other with a high performance gas chromatograpy-flame ionization detector (HPGC-FID) with a ,column. The HPGC-FID offered the best combination for the direct quantitative identification of compounds in rum concentrates. As expected, the number of compounds separated by the two procedures was the same, although some signals in the chromatogram of the packed column were too broad and unresolved. This is the case when highly polar compounds are separated in a packed column with an unmodified liquid phase such as Carbowax 20M. Twenty-two compounds were identified in one rum concentrate, 16 with a probability of $70 \%$ or higher of being correctly identified. The present procedure resulted in about a 250 to 500 fold increase in the concentration of compounds, as compared with the concentration of compounds in the original rum sample. The vast majority of these compounds were found at a concentration of $20 \mathrm{ppb}$ or less.
\end{abstract}

\section{RESUMEN}

Cromatografía de gases y espectrometría de masa para identificar compuestos en rones de Puerto Rico concentrados

Se describe un procedimiento para identificar los compuestos en rones. El mismo incluye la preparación de concentrados de rones con un concentrador tipo Kuderna y el perfil de los productos obtenidos con un sistema cromatográfico, en el que la separación con una columna de empaque se compara con una columna capilar. La columna de empaque fue conectada en el cromatógrafo defector de gas de ionización de flama (CG-DIF), mientras la columna capilar se conectó al espectrómetro de masa (EM). Las técnicas evaluadas simultáneamente proveyeron métodos alternos para

'Manuscript submitted to Editorial Board 7 October 1991.

${ }^{2}$ Chemist, Consulate, Rum Pilot Plant.

${ }^{3}$ Associate Researcher, Rum Pilot Plant. 
obtener el perfil de concentrados de rones, uno usando la columna capilar con el objetivo de obtener la identificación de los compuestos y la otra con Ia columna de empaque para la deferminación cuantitativa en los mismos concentrados. La tócnica de columna de empaque de alta eficiencia ofrece la mejor combinación para la determinación cuantitativa de los compuestos en los concentrados. Como se esperaba, el número de compuestos separados con los dos sistemas de columnas resulto ser parecido, aunque algunas señales del eromatograma de la columna de empaque resultaron bastante amplias y con poca separación entre sí. Eso es así cuando compuestos demasiado polares son separados en una fase líquida no modificada como Carbowax $20 \mathrm{M}$. El trabajo capilar con el cromatbgrafo de gas-espectrómetro de masa (CG-EM) result en la identificación de $20 \mathrm{com}$ puestos en uno de los concentrados de un ron aro, 16 de los cuales tienen una probabilidad de $70 \%$ o mejor de ser identificados correctamente.

La téenica desarrollada resultó en un aumento de la concentración de los compuestos de los concentrados de 250 a 500 veces la concentración de la muestra original. La gran mayoría de los compuestos presentes se encuentran a una concentración de 20 ppb o menors.

\section{INTRODUCTION}

The gas-chromatograph-mass spectrometry (GC-MS) analysis of distilled alcoholic beverages is one of the most demanding problems in analytical chemistry because these beverages contain a large number of compounds with only a few at sufficiently high concentrations to be detected directly by mass spectrometry. Whenever concentration is done by traditional techniques it fails because of difficulties in the separation of compounds having characteristics identical to those of the ethanol matrix. Techniques must be developed to prepare suitable concentrates: (a) solvent extraction using liquid-liquid techniques, followed by concentration under a flow of an inert gas or in a rotatory vacuum evaporator; (b) separation in a preparative column and analysis of the fraction in analytical GC columns; and (c) adsorption procedures that use selected solid adsorbents with sample recovery using appropriate solvents or by heat desorption. Rapid and direct methods for accomplishing these procedures for rum analysis with gas chromatography-flame ionization detector (GCFID), GC-MS, and high pressure liquid chromatography-mass spectrometer (HPLC-MS) without sample contamination are still required to provide suitable data for better quality determination $(4,8,12)$.

The flavor of alcoholic beverages is composed of many different volatile and non volatile compounds which give a beverage its typical aroma and taste. Nearly 1,000 compounds have been identified in different beverages $(9,10,2,15,6,17,18)$. Fusel alcohols, fatty acids, and esters form the largest groups of compounds in the volatile aroma fraction of alcoholic beverages. Other components, such as phenols, carbonyl, nitrogen and sulfur compounds, are in minor quantities, but their contribution to the 
overall quality of the beverages is significant $(15,17,18)$. In many imported foreign rums the number of compounds identified is more restricted than in other beverages, such as whiskeys, but about $400 \mathrm{com}$ pounds have been identified $(13,14)$. In Puerto Rican rums the number of components separated are fewer as we have recently reported $(1,2,4,6,7)$.

The composition of rums has been investigated extensively in the Rum Pilot Plant $(5,7)$. Moreover, these methods have been extended for the indirect and direct separations of rum components with a GC-MS utilizing a preparative column coupled to a capillary column either for GC-FID or GC-MS detection (1,2,3,4). A recent publication details recovery data which resulted in about a 1000-fold increase in the concentration of components in their own matrix compared with that of the neat rum (4). The vast majority of these components were found at concentrations as low as $0.01 \mathrm{mg} / 1 \mathrm{ml}$ with numerous signals identified in the chromatogram not previously observed in Puerto Rican rums.

Although a high degree of concentration was achieved, it was our objective in the research here reported to assess a different simple technique, based on Kuderna concentrator (KC), for concentrating rum, and to identify many components of rum found in extremely smaller amounts, and at the same time, to have on hand a method suitable for routine analysis.

\section{MATERIALS AND METHODS}

\section{GC-FID and GC-MS Profiles and Kuderna concentrator}

A Hewlett Packard 5890A GC-MS was used to conduct capillary column separation for the MS profiles and a packed column for the GC-FID work. This instrument is a dual injector unit with a split/splitless capillary column inlet and a packed column inlet. It has an FID, an HP5970B MSD quadrupole stand-alone GC detector, and an HP59970C Chemstation with a HP5990C computer, hard drive, disk drive and printer. The GC-MS system includes all the necessary software and NBS, NHI, EPA Data Base MS library with mass spectral data for 45,000 compounds.

The capillary column used for the GC-MS work was a Supelcowax $10^{4}$ coated on a $30 \mathrm{~m} \times 0.25 \mathrm{~mm}$ i.d., $0.25 \mu \mathrm{m}$ film thickness fused silica capillary tubing, connected to the MS probe through one of the injection ports of the unit. For the GC-FID work, an analytical packed column (PPR187), $18 \mathrm{ft} \times 1 / 8 \mathrm{in}$. OD SS containing $5 \%$ Carbowax $20 \mathrm{M}$ coated on $60 / 80$ Chromosorb W. a/w. was connected to the FID of the GC/MS through the other injection port.

Figure 1 shows the Kuderna concentrator. It has been used to concentrate organic contaminants in water and waste water by stripping the sample of contaminants with an organic solvent denser than water. 


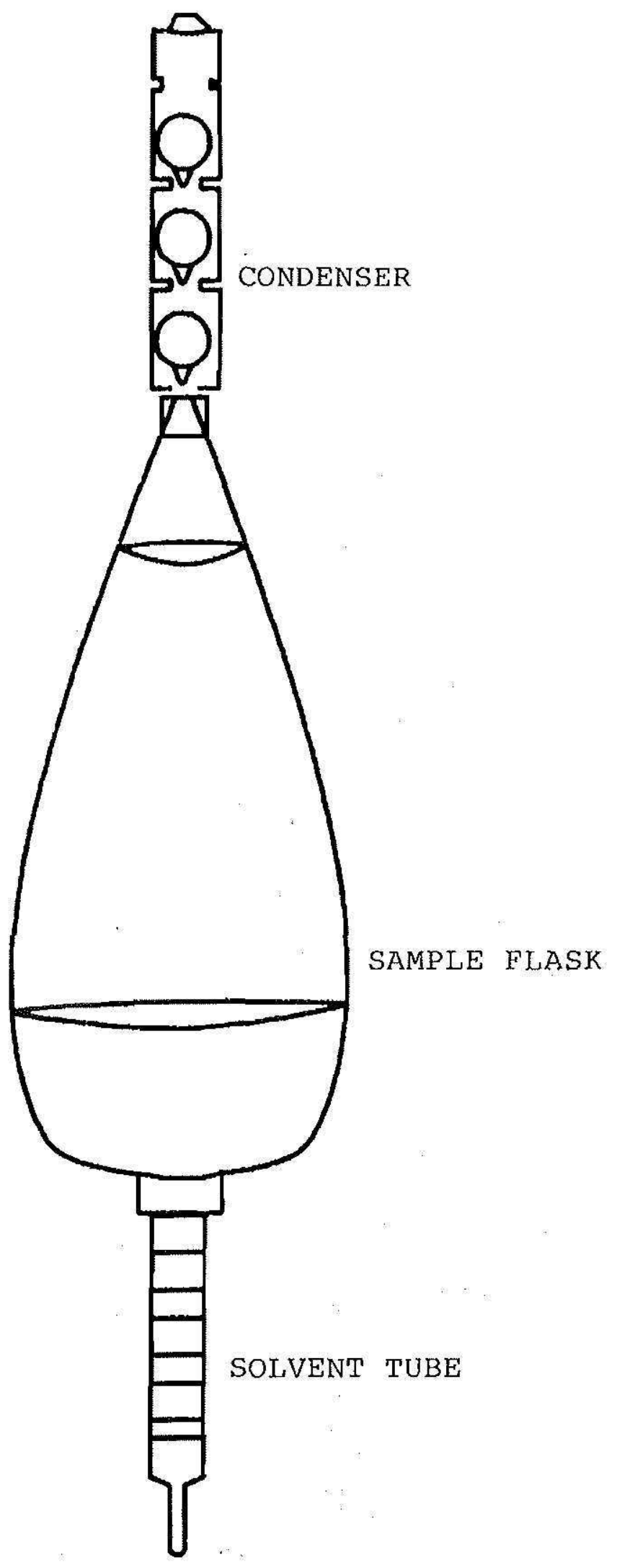

FIG. 1.-Kuderna concentrator. 


\section{SAMPLE CONCENTRATION AND ANALYSIS}

To evaluate the Kuderna concentrator, we placed $500 \mathrm{ml}$ of the appropriate rum in the middle sample flask (fig. 1) and charged the concentrator with a given volume of spectral gxade dichloromethane, which fell to the concentrating tube below. Similar samples were extracted with boiling $10,15,30,50$, or $100 \mathrm{ml}$ portions of spectral grade dicloromethane $\left(\mathrm{CH}_{2} \mathrm{Cl}_{2}\right)$ at $40^{\circ} \mathrm{C}$ during a 6 -hour period. We found this 6 -hour period to be the most adequate for a given extraction after we had treated a $500-\mathrm{ml}$ sample with $100 \mathrm{ml} \mathrm{CHl}$, at different extraction periods $1,3,5$, 8, and 24 hours. We further concentrated the dichloromethane extracts to a small volume ina $100-\mathrm{ml}$ saperatory funnel connected to a calibrated 5$\mathrm{ml}$ cylinder by blowing pure helium through the sample. The final volume of the reduced extract was difficult to control under these conditions, but about $2 \mathrm{ml}$ was an appropriate volume. For comparison, we reduced an extract to small volume in a rotatory evaporator, but this procedure was tedious and the final volume of the extract was more difficult to control under these conditions.

The untreated (neat) and the concentrated samples were separated both with the capillary and the packed analytical columns at conditions

given in table 1. Table 2 shows the GC-MS conditions for the GC-MS profiles:

Samples and extracts

\section{A. GOLD LABEL RUM}

$\mathrm{R}-818$ is an $80^{\circ} \mathrm{P}$ gold label commercial rum.

R-818-1 is an R-818 rum extract, $500-\mathrm{ml}$ sample extracted for 6 hours with $50 \mathrm{ml} \mathrm{CH}_{2} \mathrm{Cl}_{2}$.

$\mathrm{R}-818-3$ is an R-818-1 extract reduced to $2 \mathrm{ml}$ under a flow of pure helium. $\mathrm{R}-830$ is an $80^{\circ} \mathrm{P}$ gold label commercial rum.

R-830-1 is an R-830 rum extract, 500 -ml sample extracted for 6 hours with $50 \mathrm{ml} \mathrm{CH}_{2} \mathrm{Cl}_{2}$.

R-830-2 is an R-830-1 extract reduced to $1 \mathrm{ml}$ under a flow of pure helium. R-830-3 is an R-830 extract, 500-ml sample extracted for 6 hours with $100 \mathrm{ml} \mathrm{CH}_{2} \mathrm{Cl}_{2}$.

$\mathrm{R}-830-4$ is an R-830-3 extract reduced to $2 \mathrm{ml}$ under a flow of pure helium. $\mathrm{R}-830-5$ is an R-830 extract, $500-\mathrm{ml}$ sample extracted for 6 hours with 30 $\mathrm{ml} \mathrm{CH} \mathrm{Cl}_{2}$, reduced to $2 \mathrm{ml}$ under a flow of helium.

$\mathrm{R}-830-6$ is an R-830-5 extract reduced to $1.9 \mathrm{ml}$ under a flow of pure helium.

R-830-7 is an R-830 extract, $500 \mathrm{ml}$ extracted for 6 hours with $100 \mathrm{ml}$ $\mathrm{CH}_{2} \mathrm{Cl}_{2}$.

$\mathrm{R}-830-8$ is an $\mathrm{R}-830-7$ reduced to $3.0 \mathrm{ml}$ in a rotatory evaporator $\left(40-50^{\circ} \mathrm{C}\right.$ at reduced pressure). 


\section{B. WHITE LABEL RUM}

R-831 is an $80^{\circ} \mathrm{P}$ white label commercial rum.

R-831-3 is an R-831 rum extract, $500-\mathrm{ml}$ sample extracted for 6 hours with $100 \mathrm{ml} \mathrm{CH}_{2} \mathrm{Cl}_{2}$.

$\mathrm{R}-831-5$ is an R-831 rum extract, $500-\mathrm{ml}$ sample extracted for 6 hours with $30 \mathrm{ml} \mathrm{CH} \mathrm{Cl}_{2}$.

$\mathrm{R}-831-6$ is an R-831-5 extract reduced to $1.6 \mathrm{ml}$ under a flow of pure helium.

R-831-7 is an R-831 extract, $500-\mathrm{ml}$ sample extracted for 6 hours with $100 \mathrm{ml} \mathrm{CH} \mathrm{Cl}_{2}$.

$\mathrm{R}-831-8$ is an $\mathrm{R}-831-7$ extract reduced to $3.0 \mathrm{ml}$ in a rotatory evaporator $\left(40-50^{\circ} \mathrm{C}\right.$ at reduced pressure).

\section{RESULTS AND DISCUSSION}

The chromatograms of white- and gold-label rums obtained with packed column PPR-187 (FID Method) are reproduced in figures 2 through 7. Figure 2 is the PPR-187-packed-column chromatogram of 3- $\mu$ ! samples, (A) the neat R-818 sample, (B) R-818-1 dichloromethane rum extract, and (C) R-818-3 reduced dichloromethane extract. Figure 3 is the PPR-187 packed-column chromatogram of 3- $\mu$ l samples; (A) is the neat sample R-830, (B) R-830-3 dichloromethane rum extract, and (C) R-830-5 reduced dichloromethane extract Figure 4 is the PPR-187packed-column chromatogram of 3- $\mu$ l samples; (A) is the neat R-830 sample, (B) R-830-4 reduced dichloromethane extract, and (C) R-830-2 reduced dichloromethane extract). Figure 5 is the PPR-187-packed-column

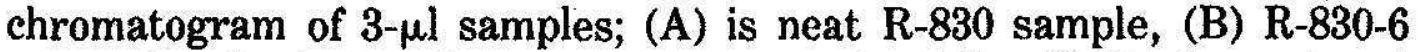
reduced dichloromethane extract, and (C) R-830-8 reduced

TABLE 1.-Sample and extract conditions for the chromatographic column

\begin{tabular}{lcc}
\hline FUNCTION & $\begin{array}{c}\text { PPR }-187 \\
\text { COLUMN }\end{array}$ & $\begin{array}{c}\text { CAPILLARY } \\
\text { COLUMN }\end{array}$ \\
\hline Pressure & $60 \mathrm{psi}$ & $12 \mathrm{psi}$ \\
Flow & $50 \mathrm{ml} / \mathrm{min}$ & $1 \mathrm{ml} / \mathrm{min}$ \\
$\mathrm{T}_{i}$ (level 1) & $58^{\circ} \mathrm{C}$ & $50^{\circ} \mathrm{C}$ \\
$\mathrm{T}_{i}$ (level 2) & - & $150^{\circ} \mathrm{C}$ \\
$\mathrm{T}_{\mathrm{f}}$ (level 3) & $140^{\circ} \mathrm{C}$ & $170^{\circ} \mathrm{C}$ \\
$\mathrm{t}_{\mathrm{i}}$ (level 1) & $6 \mathrm{~min}$ & $6 \mathrm{~min}$ \\
$\mathrm{t}_{\mathrm{i}}$ (level 2) & - & $2 \mathrm{~min}$ \\
$t_{f}$ (level 3) & $12 \mathrm{~min}$ & $10 \mathrm{~min}$ \\
Temp. Prog. (level 1) & $20 \mathrm{C} / \mathrm{min}$ & $10^{\circ} \mathrm{C} / \mathrm{min}$ \\
Temp. Prog. (level 2) & - & $10^{\circ} \mathrm{C} / \mathrm{min}$ \\
Splitter ratio & - & $1: 30$ \\
\hline
\end{tabular}


J. Agric. Univ. P.R. Vol. 77, No. 1-2, JANUARY/APRIL, 199375

TABLE 2,-Conditions for the FC-MS profiles

SCAN ACQUISITION DATA: CONCRON.A

\begin{tabular}{ccccccc} 
Solvent & Delay & 0.00 & eM volts & o relative & $\begin{array}{c}\text { Resulting } \\
\text { voltage }\end{array}$ & 1800 \\
\hline & $\begin{array}{c}\text { Start } \\
\text { time }\end{array}$ & $\begin{array}{c}\text { Low } \\
\text { mass }\end{array}$ & $\begin{array}{c}\text { High } \\
\text { mass }\end{array}$ & $\begin{array}{c}\text { Scan } \\
\text { threshold }\end{array}$ & $\begin{array}{c}\text { a/d samples } \\
(2 \hat{N})\end{array}$ & $\begin{array}{c}\text { Scan per } \\
\text { second }\end{array}$ \\
\hline 1 & 0.00 & 25.0 & 103.0 & 2000 & 1 & 10.9 \\
2 & 3.00 & 25.0 & 100.0 & 2000 & 1 & 11.4 \\
3 & 15.00 & 25.0 & 550.0 & 1000 & 2 & 0.82 \\
\hline
\end{tabular}

TEMPERATURE PROGRAM \& HEATED ZONES

\begin{tabular}{ccccccc} 
Run time & 30.00 & Equilibration & time & 0.50 & $\begin{array}{c}\text { Purge } \\
\text { off time }\end{array}$ & 0.00 \\
\hline Level & $\begin{array}{c}\text { Initial } \\
\text { temp. }\end{array}$ & $\begin{array}{c}\text { Initial } \\
\text { time }\end{array}$ & $\begin{array}{c}\text { Rate } \\
\left({ }^{\circ} \mathrm{C} / \mathrm{min}\right)\end{array}$ & $\begin{array}{c}\text { Final } \\
\text { temp. }\end{array}$ & $\begin{array}{c}\text { Final } \\
\text { time }\end{array}$ & $\begin{array}{c}\text { Total } \\
\text { time }\end{array}$ \\
\hline 1 & 50 & 6.00 & $\$ 0.0$ & 150 & 2.00 & 18.00 \\
2 & & & 10.0 & 170 & 10.00 & 30.00 \\
\hline & & & Actual & Setpoint & & Limit \\
Oven & & & & & \\
(Standby) & & & 50 & 50 & & 180 \\
Inj Port B & & & 200 & 200 & & 200 \\
Detector A & & 280 & 280 & & 280 \\
Inj Port A & & 200 & 200 & & 250 \\
Transfer Line & & & 280 & 280 & & 280 \\
\hline
\end{tabular}

RUN TABLE EDITOR

0.00 Valves Divert On

0.75 Valves Divert Off

2.00 Mass Sp Off

5.00 Mass Sp On

30.00 Stop Run

dichloromethane extract. Figure 6 is the PPR-187-packed-column chromatogram of 3- $\mu$ l samples; (A) is the neat R-831 sample, (B) R-831-7 dichloromethane-rum extract, and (C) R-830-8 reduced dichloromethane extract, and figure 7 is the PPR-187-packed-column chromatogram of 3- $\mu$ l samples; (A) is neat R-831, (B) R-830-6 reduced dichloromethane extract, and (C) R-831-8 reduced dichloromethane extract.

The GC-MS profiles are shown in figures 8 through 17. Figure 8 is the capillary column GC-MS total ion chromatogram of neat sample R818 , and figure 9 is the corresponding capillary column GC-MS total ion 


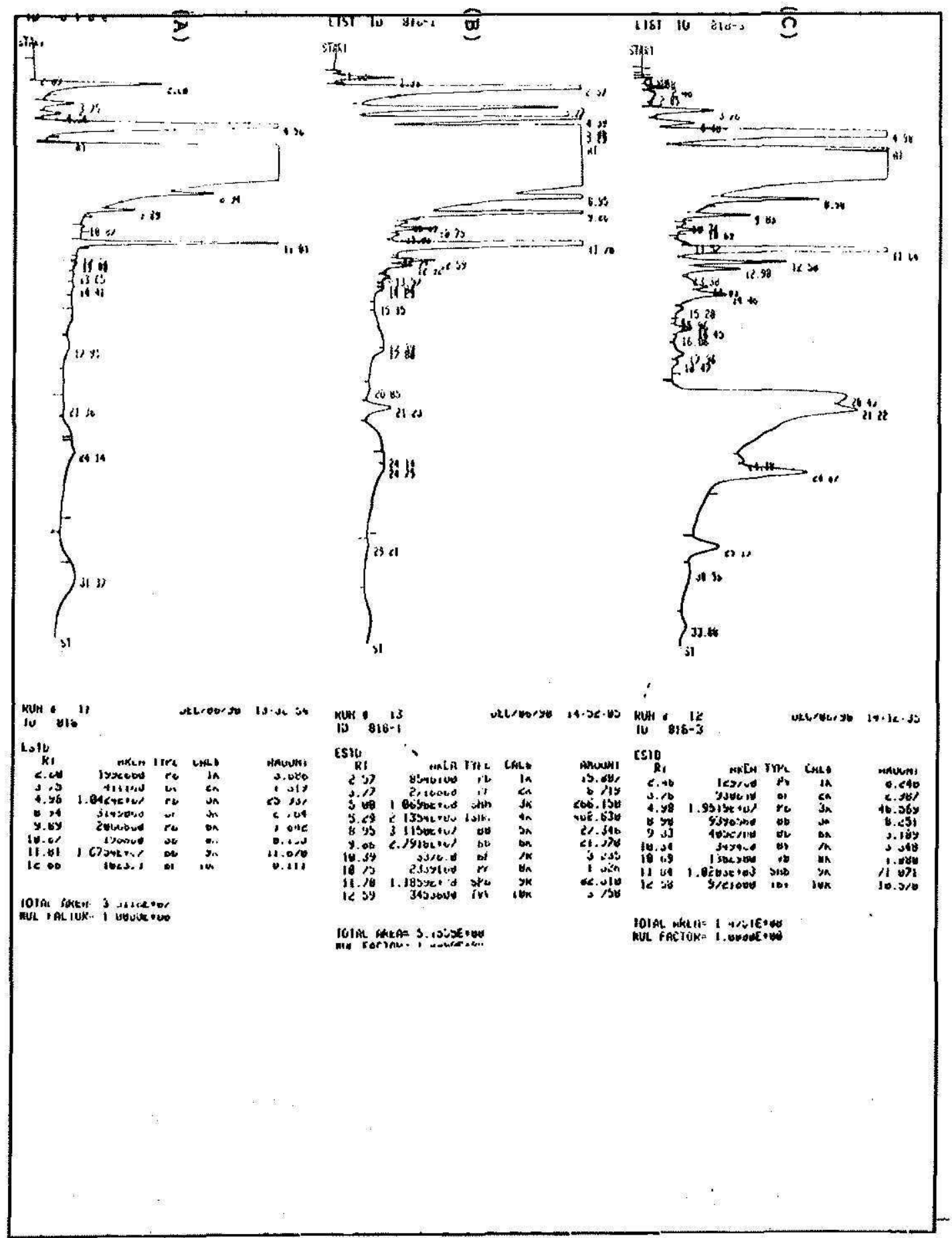

FiG. 2.-Analytical FID chromatogram (PPR-187) of 3ul R-818 samples: (A) neat rum, (B) 500:50 rum: $\mathrm{CH}_{2} \mathrm{Cl}_{2}$, and (C) $50 \mathrm{ml}$ of $\mathrm{CH}_{2} \mathrm{Cl}_{2}$ (500:50 rum: $\mathrm{CH}_{2} \mathrm{Cl}_{2}$ ) reduced to $2 \mathrm{ml}$. 


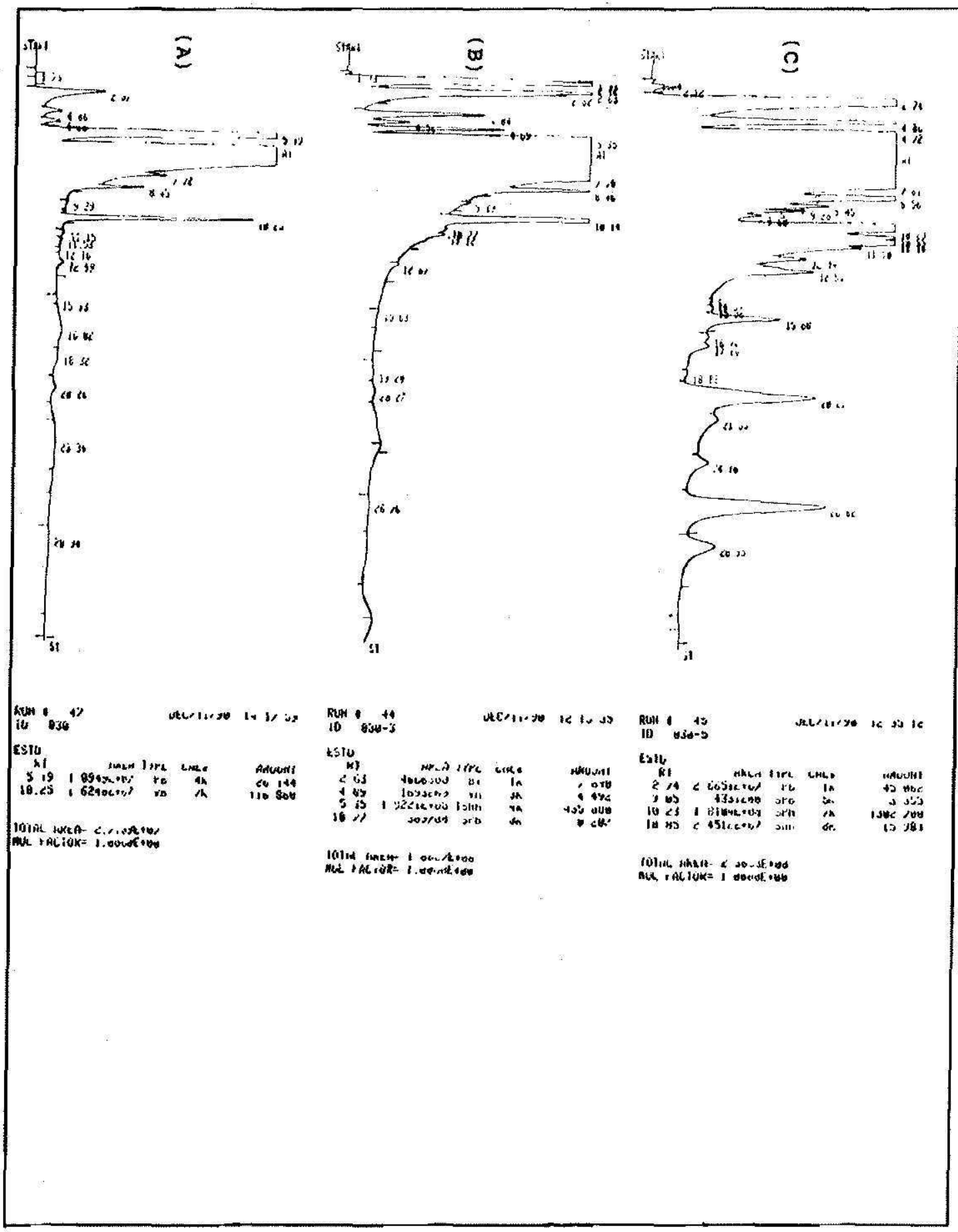

F1G. 3.-Analytical FID chromatogram (PPR-187) of 3ul R-830 samples: (A) neat rum, (B) 500:100 rum: $\mathrm{CH}_{2} \mathrm{Cl}_{2}$ and (C) 100ml of $\mathrm{CH}_{2} \mathrm{Cl}_{2}$ (500:100 rum: $\mathrm{CH}_{2} \mathrm{Cl}_{2}$ ) reduced to $2 \mathrm{ml}$. 

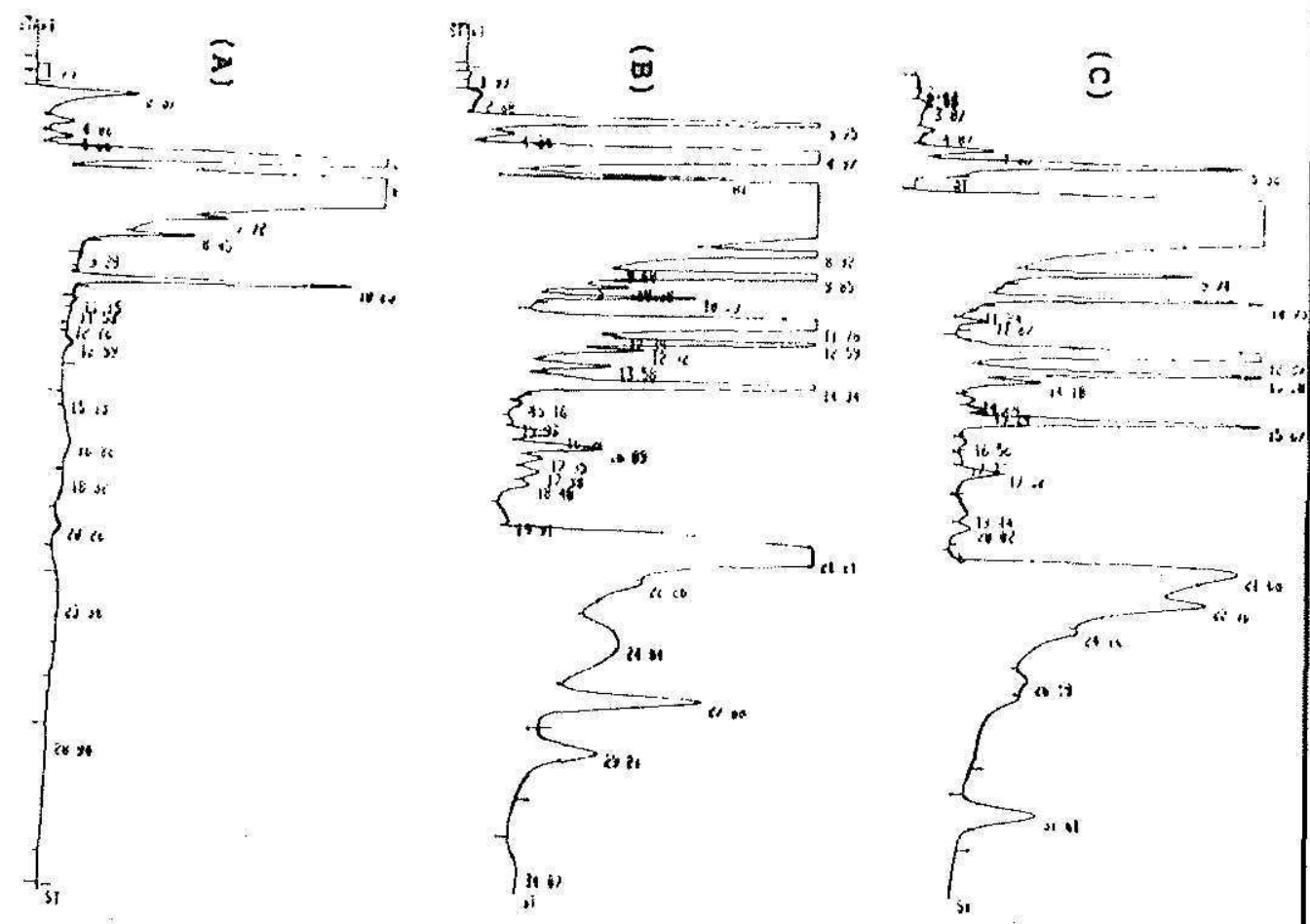

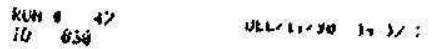

Es:

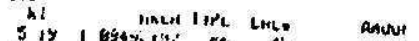

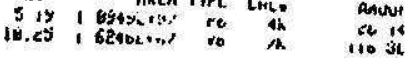

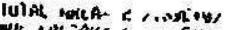

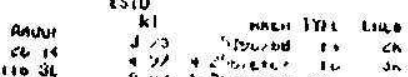

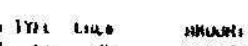
to sushow bre in

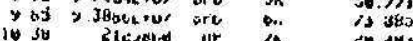

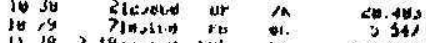

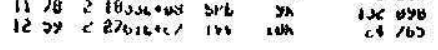

lothat flich: treit ons

Uk: i vit tow

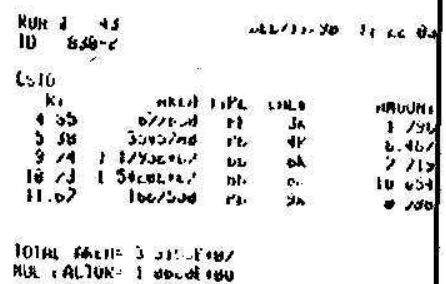

Fig. 4.-Analytical FID chromatogram (PPR-187) of 3ul R-830 samples; (A) neat rum, (B) $100 \mathrm{ml}$ of $\mathrm{CH}_{2} \mathrm{Cl}_{2}$ (500:100 rum: $\mathrm{CH}_{2} \mathrm{Cl}_{2}$ ) reduced to $2 \mathrm{ml}$, and (C) $50 \mathrm{ml}$ of $\mathrm{CH}_{2} \mathrm{Cl}_{2}$ (500:50 rum: $\mathrm{CH}_{2} \mathrm{Cl}_{2}$ ) reduced to $\mathrm{Iml}$. 


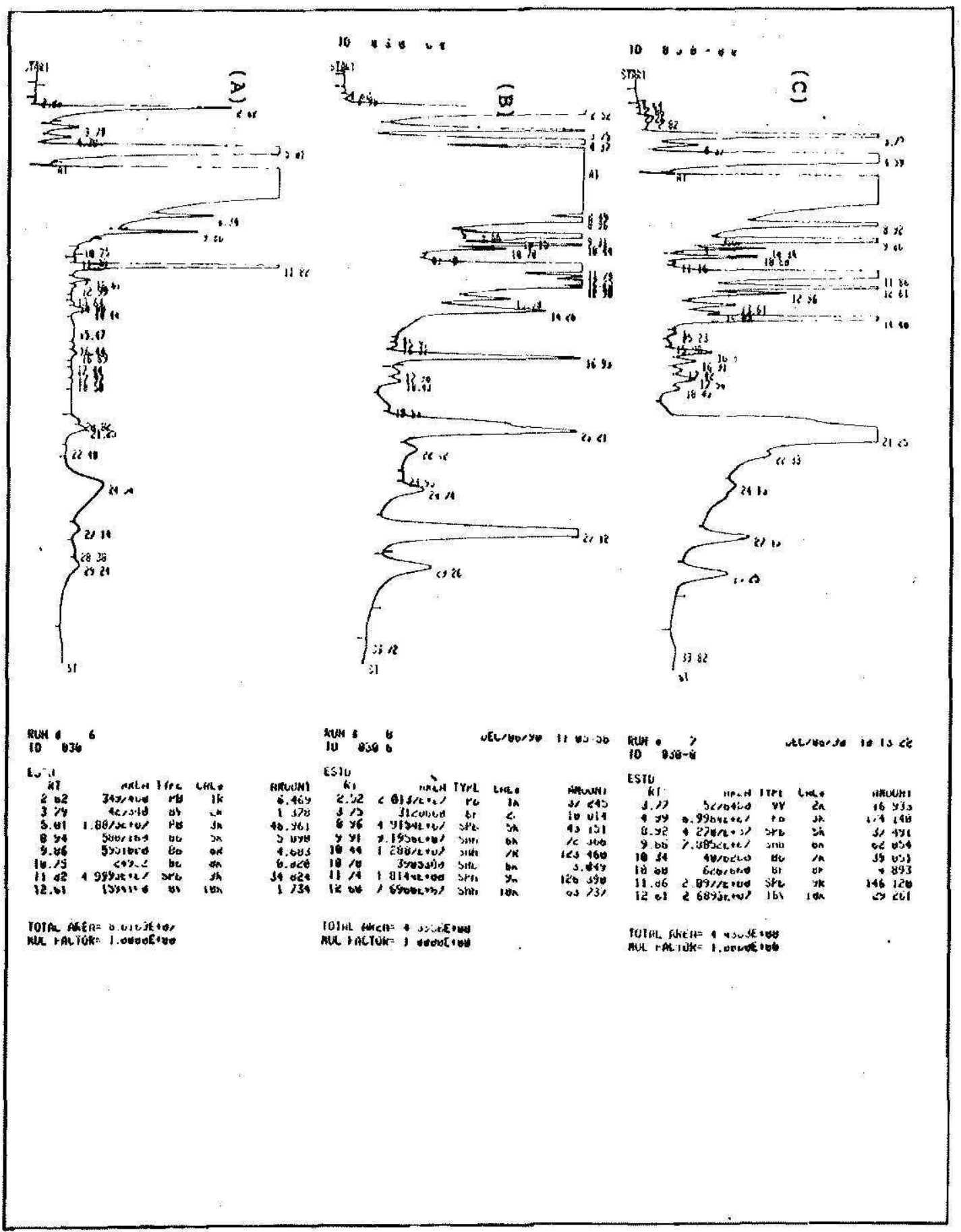

Fic. 5.-Analytical FID chromatogram (PPR-187) of 3ul R-830 samples: (A) neat rum, (B) $100 \mathrm{ml}$ of $\mathrm{CH}_{2} \mathrm{Cl}_{2}\left(500: 100\right.$ rum: $\left.\mathrm{CH}_{2} \mathrm{Cl}_{2}\right)$ reduced to $2 \mathrm{ml}$, and (C) $100 \mathrm{ml}$ of $\mathrm{CH}_{2} \mathrm{Cl}_{2}$ 500:100 rum: $\mathrm{CH}_{2} \mathrm{Cl}_{2}$ ) reduced to $3 \mathrm{ml}$. 


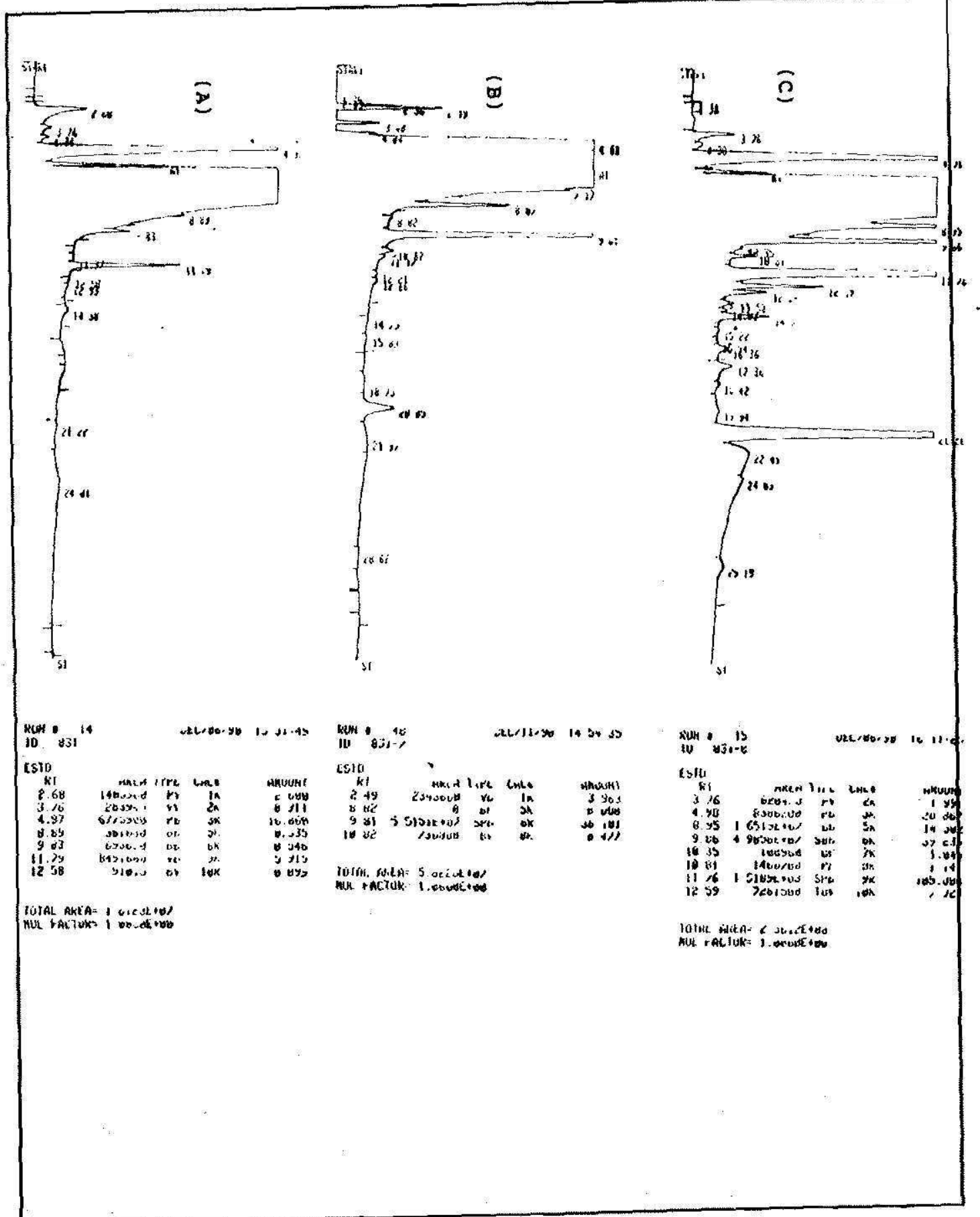

FIG. 6. - Analytical FID chromatogram (PPR-187) of 3ul R-831 samples: (A) neat rum, (B) 500:100 rum: $\mathrm{CH}_{2} \mathrm{Cl}_{2}$ and (C) $100 \mathrm{ml}$ of $\mathrm{CH}_{2} \mathrm{Cl}_{2}$ (500:100 rum: $\mathrm{CH}_{2} \mathrm{Cl}_{2}$ ) reduced to $3 \mathrm{ml}$. 


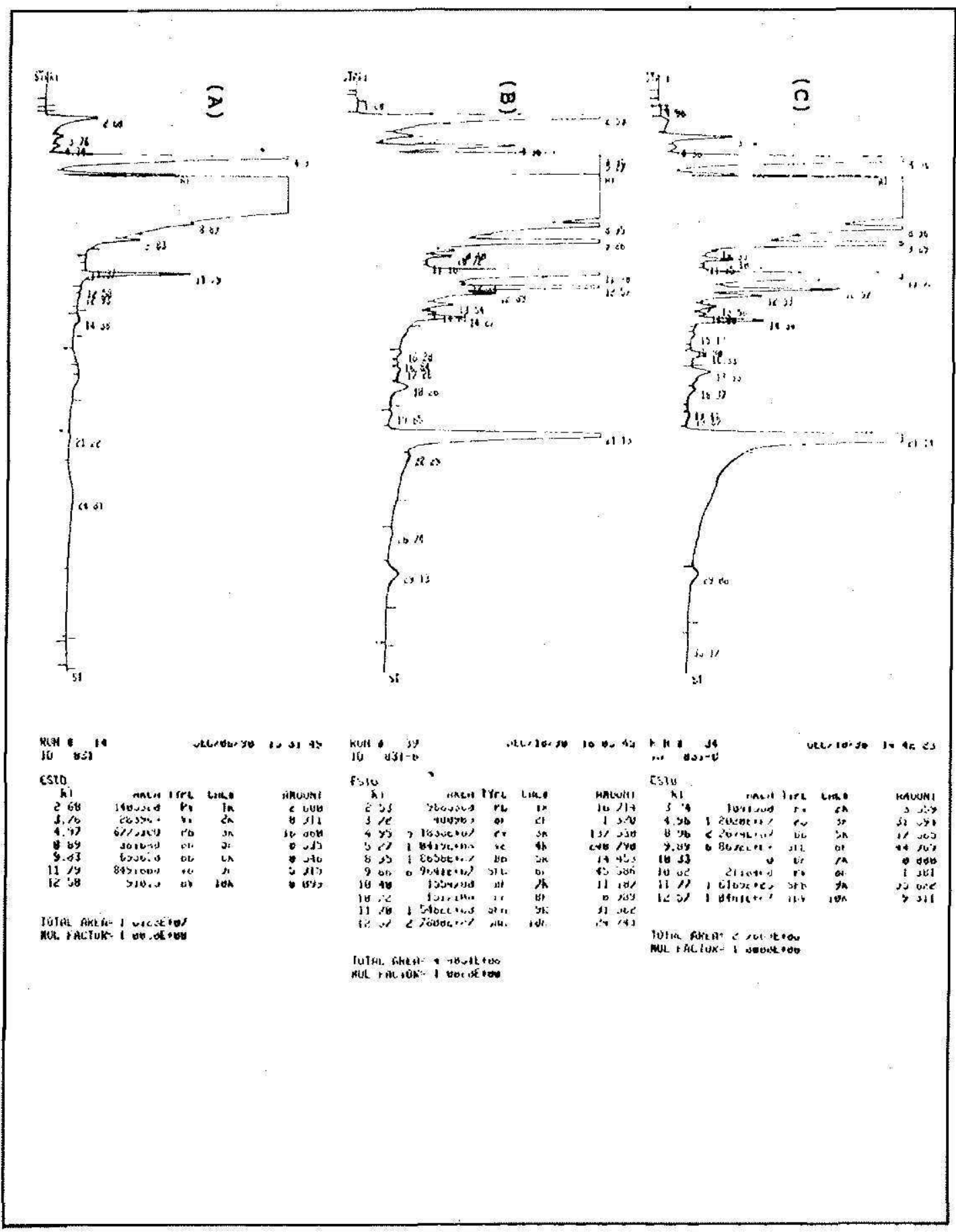

Fic. 7.- Analytical FID chromatogram (PPR-187) of 3ul R-831 samples: (A) neat rum, (B) $100 \mathrm{ml}$ of (500-100 rum: $\mathrm{CH}_{2} \mathrm{Cl}_{2}$ ) reduced to $1.9 \mathrm{ml}$, and (C) $100 \mathrm{ml}$ of $\mathrm{CH}_{2} \mathrm{Cl}_{2} 500: 100$ rum: $\mathrm{CH}_{2} \mathrm{Cl}_{2}$ ) reduced to $3 \mathrm{ml}$. 


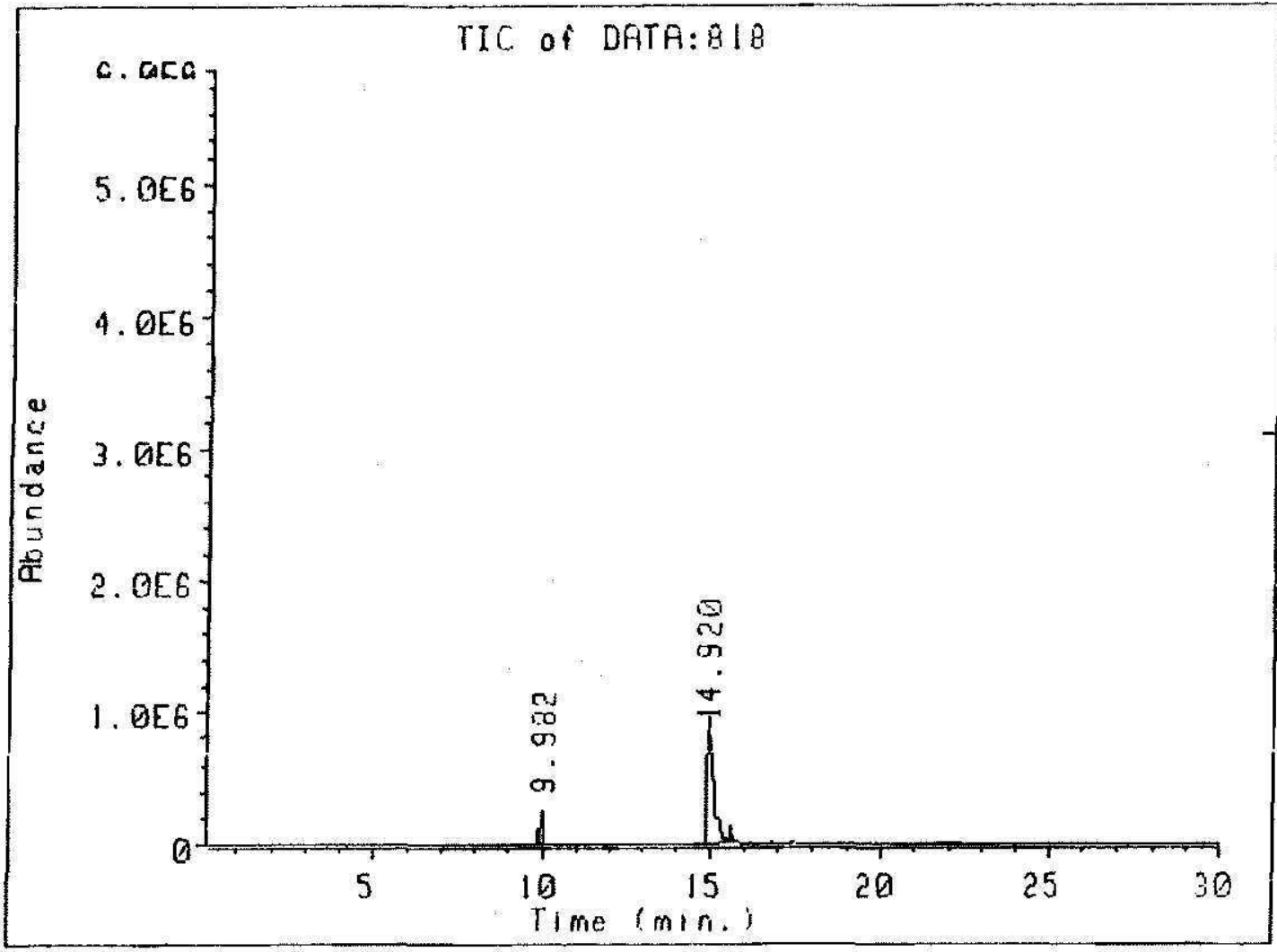

TIC of DATA:818

$\begin{array}{rrcrrrr}\text { Peak \# } & \text { Ret Time } & \text { Type } & \text { Width } & \text { Area } & \text { Start Time } & \text { End Time } \\ 1 & 9.982 & \text { VH } & 0.059 & 10391076 & 9.879 & 10.030 \\ 2 & 14.920 & \text { BV } & 0.151 & 116709662 & 14.854 & 15.608\end{array}$

Fig. 8. - Capillary column GC-MS total ion chromatogram of neat R-818.

chromatogram of R-818-3 reduced dichloromethane extract. Figure 10 is the capillary column GC-MS total ion chromatogram of neat sample R-830 and figures $11,12,13$, and 14 are the corresponding capillary column GC-MS total ion chromatograms of the reduced dichloromethane extracts of R-830-2, R-830-4, R-830-6, and R-830-8, respectively. Figure 15 is the capillary column GC-MS total ion chromatogram of neat sample R-831. Figures 16 and 17 are the corresponding capillary column GC-MS total ion chromatograms of the reduced dichloromethane extracts of R-831-6, and $\mathrm{R}-831-8$, respectively.

The application of two different procedures for the separation of the concentrates was necessary in order to have alternative methods available, one with a capillary column just for identification purpose, and a packed column for the quantification of identified components. Since the HPGC-FID combination offers the best choice for quantification, it was 
included as an important component in this study. It was not unexpected that the number of compounds separated by the two procedures was the same, although some signals in the chromatogram of the packed column were too broad and unresolved. This is the case when highly polar compounds are separated in a packed column with an unmodified liquid phase such as Carbowax 20M.

Table 3 presents the list of compounds identified by means of the NBS Library in the chromatogram of the GC-MS profile of the R-830-6 rum extract (fig. 13).

Twenty-two compounds were identified in the rum extract, 16 with a probability of $70 \%$ or higher of being correctly identified. According to the HP Manual, PBM Search and Parametric Retrieval Software, a probability of less than $50 \%$ represents a significant difference between the unknown signal and the reference data, whereas values higher than $90 \%$ will correspond perfectly with the component to be identified. In order

TABLE 3.-Compounds idenlified by means of GC.MS NBS Library

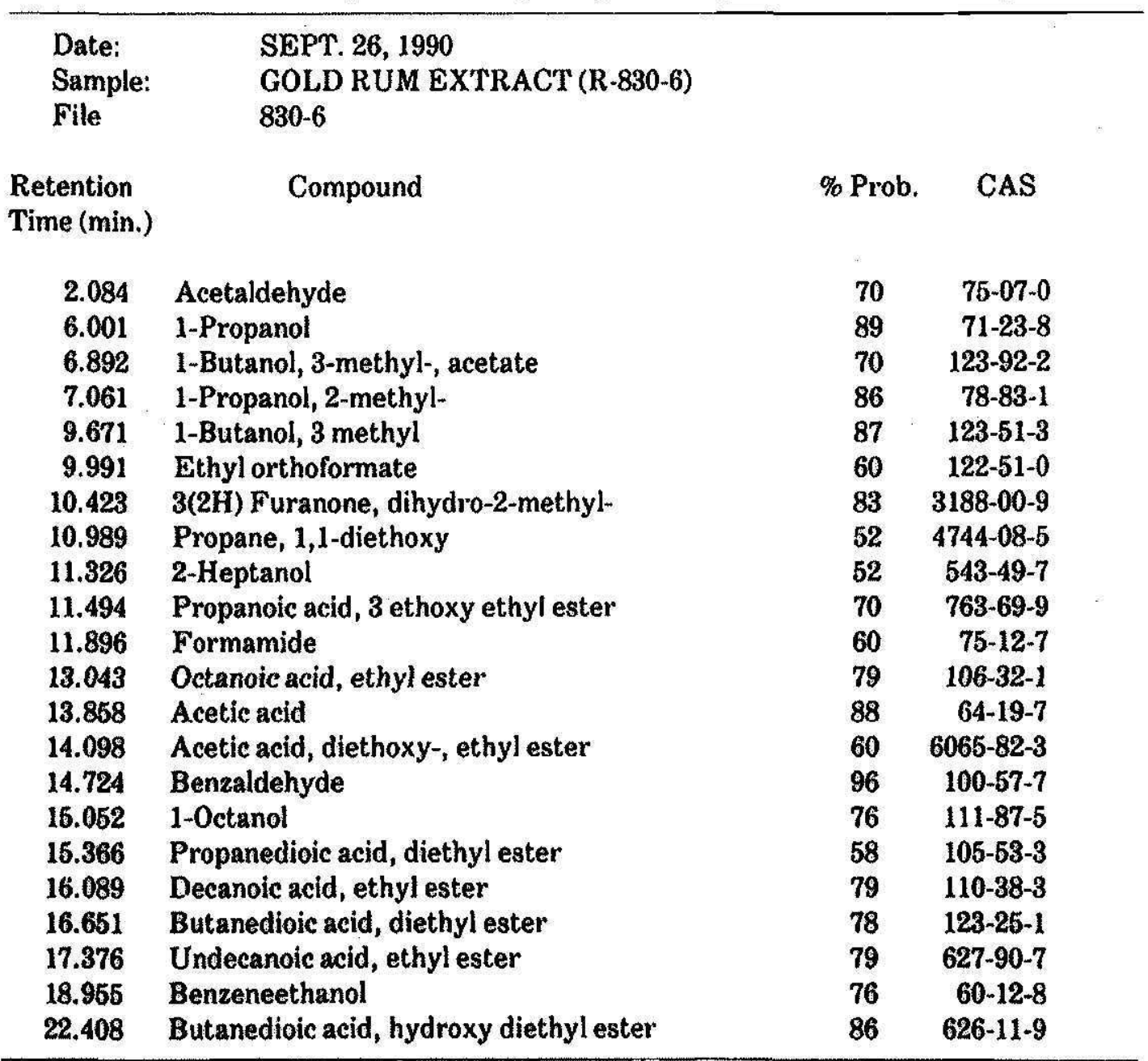




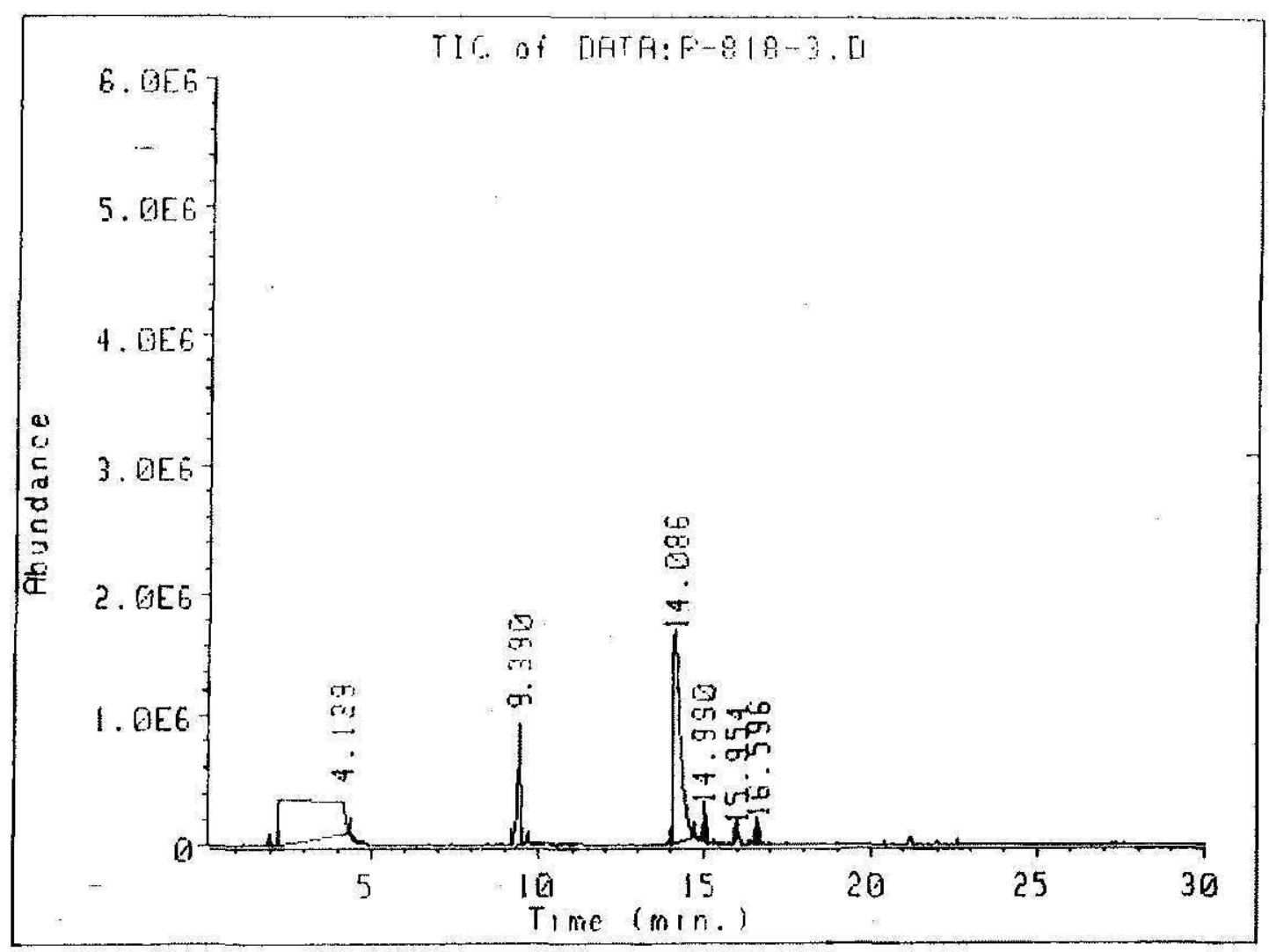

TIC of DATA:R-818-3.D

CONC. R-818, EXT. $\mathrm{CH}_{2} \mathrm{CL}_{2}$

$\begin{array}{rrlrrrr}\text { Peak \# } & \text { Ret Time } & \text { Type } & \text { Width } & \text { Area } & \text { Start Time } & \text { End Time } \\ 1 & 4.129 & \text { BV } & 0.747 & 164291729 & 2.224 & 4.343 \\ 2 & 9.390 & \text { BV } & 0.077 & 51657685 & 9.164 & 9.527 \\ 3 & 14.086 & \text { PV } & 0.163 & 223070757 & 14.020 & 14.721 \\ 4 & 14.990 & \text { VB } & 0.032 & 5997250 & 14.949 & 15.137 \\ 5 & 15.954 & \text { PV } & 0.035 & 1993047 & 15.862 & 15.981 \\ 6 & 16.596 & \text { VV } & 0.041 & 6002249 & 15.524 & 16.679\end{array}$

Frg. 9.- Capillary column GC-MS total ion chromatogram of R-818 reduced dichloromethane extract. 
J. Agric. Univ. P.R. VoL. 77, NO. 1-2, JANUARY/APRIL, 199385

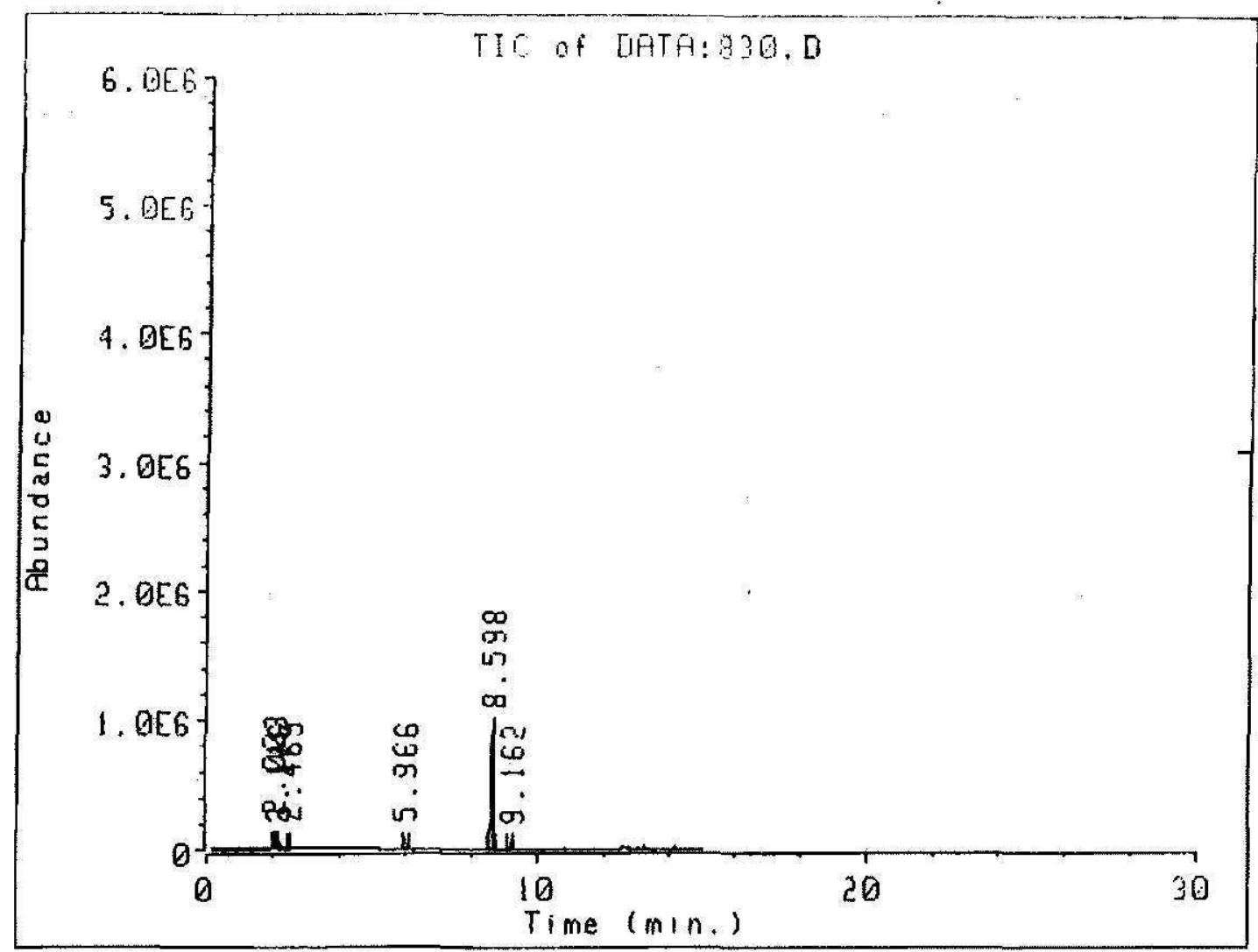

TIC of DATA:830.D

$\begin{array}{rrlrrrr}\text { Peak \# } & \text { Ret Time } & \text { Type } & \text { Width } & \text { Area } & \text { Start Time } & \text { End Time } \\ 1 & 2.003 & \text { VV } & 0.038 & 2548306 & 1.949 & 2.039 \\ 2 & 2.116 & \text { PV } & 0.028 & 1228714 & 2.079 & 2.152 \\ 3 & 2.465 & \text { BB } & 0.024 & 1071885 & 2.431 & 2.529 \\ 4 & 5.966 & \text { BV } & 0.063 & 3380387 & 5.897 & 6.083 \\ 5 & 8.598 & \text { BV } & 0.048 & 32343795 & 8.457 & 8.657 \\ 6 & 9.162 & \text { BB } & 0.031 & 1160433 & 9.004 & 9.236\end{array}$

Fig. 10.-Capillary column GC-MS total ion chromatogram of neat R-830. 


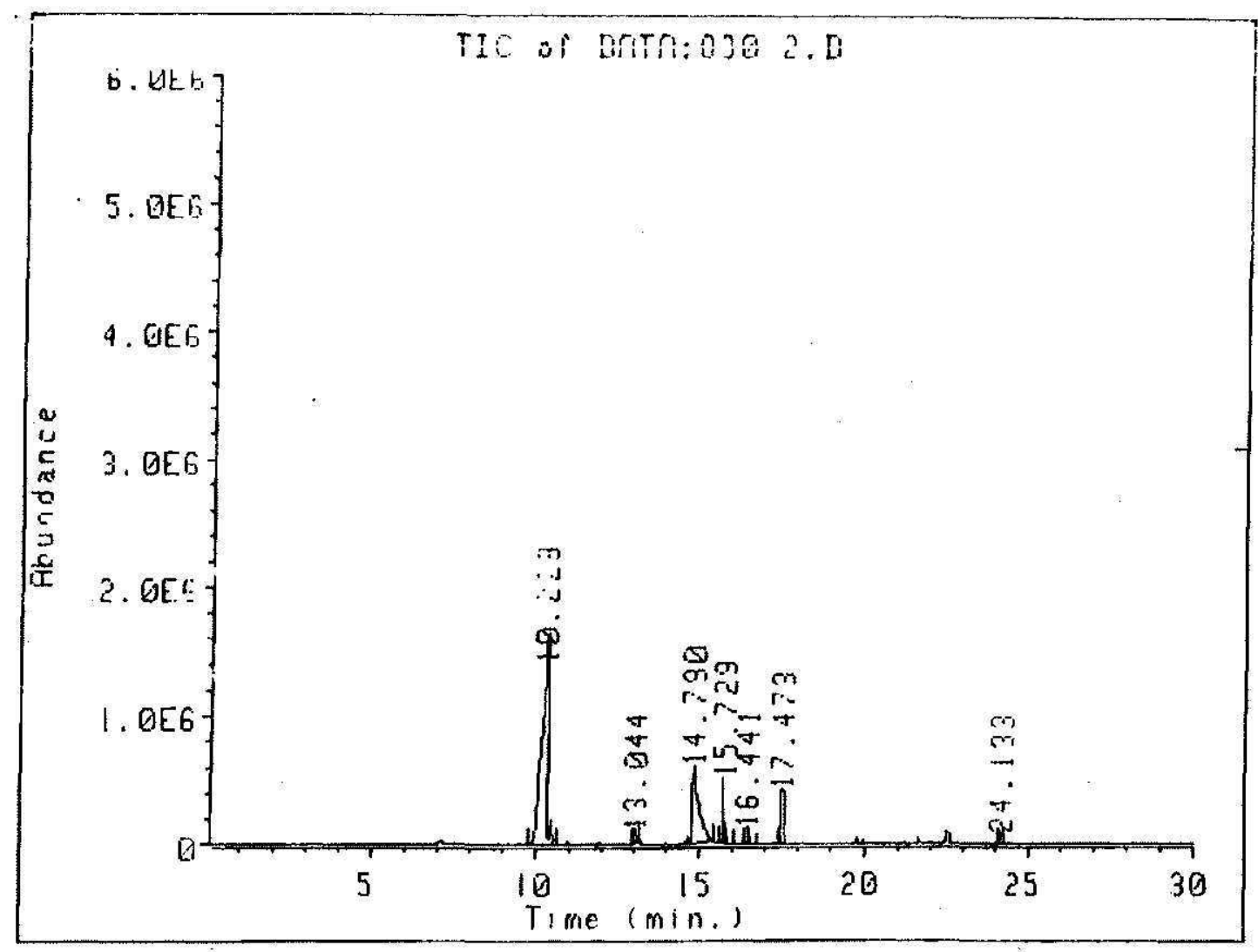

TIC of DATA:830-2.D

$\begin{array}{rrlrrrr}\text { Peak \# } & \text { Ret Time } & \text { Type } & \text { Width } & \text { Area } & \text { Start Time } & \text { End Time } \\ 1 & 10.229 & \text { BH } & 0.267 & 220237489 & 9.717 & 10.609 \\ 2 & 13.004 & \text { BV } & 0.082 & 7497653 & 12.953 & 13.170 \\ 3 & 14.790 & \text { BV } & 0.176 & 83683842 & 14.759 & 15.382 \\ 4 & 16.729 & \text { BB } & 0.044 & 15760626 & 15.601 & 15.821 \\ 5 & 16.441 & \text { BB } & 0.044 & 3386783 & 16.366 & 16.508 \\ 6 & 17.473 & \text { BB } & 0.047 & 15231604 & 17.393 & \$ 7.551 \\ 7 & 24.133 & \text { BB } & 0.059 & 4264161 & 24.049 & 24.211\end{array}$

FrG. 11.-Capillary column GC-MS total ion chromatogram of R-830 reduced dichloromethane extract. 


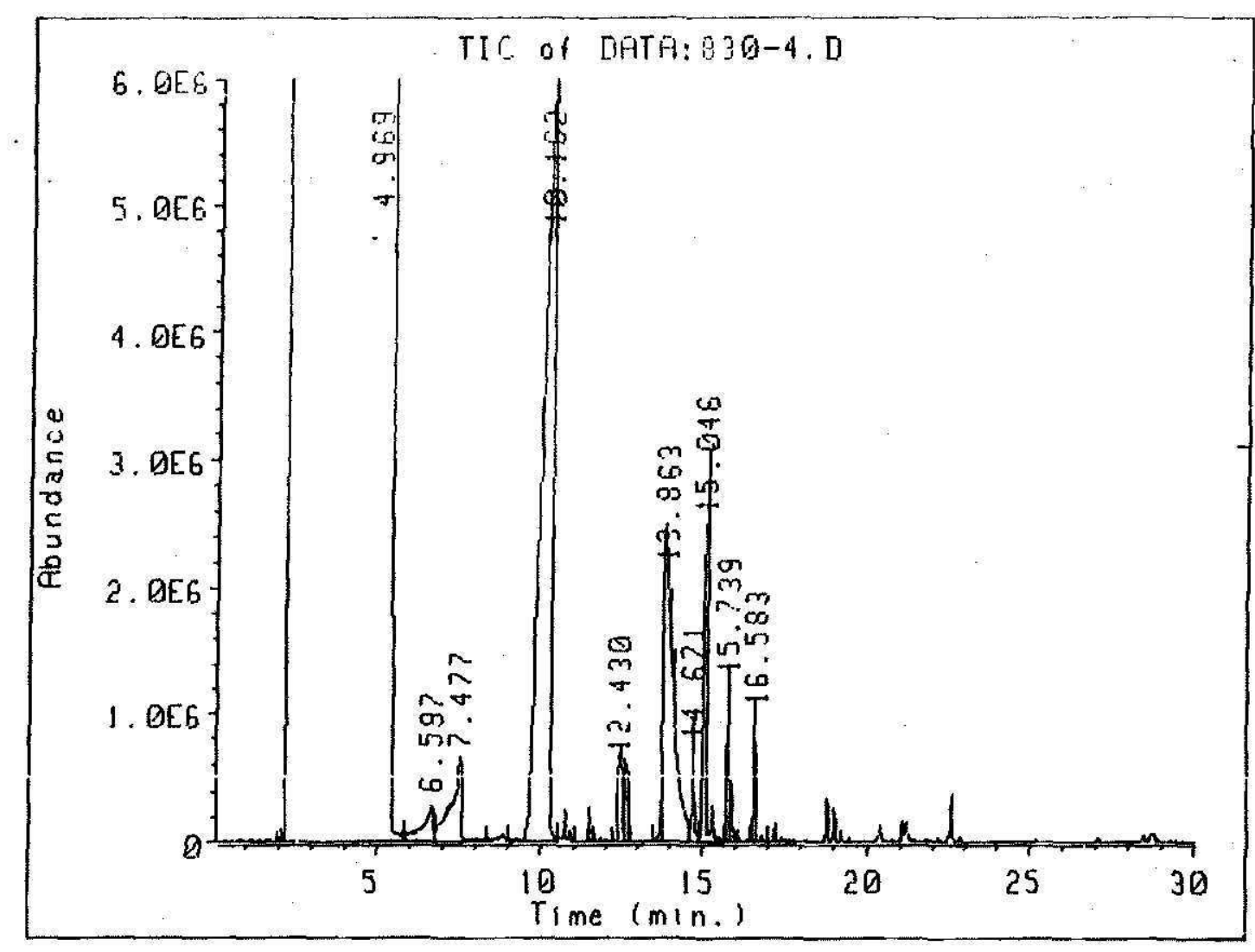

TIC of DATA:830-4.D

$\begin{array}{rrlrrrr}\text { Peak \# } & \text { Ret Time } & \text { Type } & \text { Width } & \text { Area } & \text { Start Time } & \text { End Time } \\ 1 & 4.969 & \text { BV } & 1.328 & 12246059030 & 2.103 & 5.800 \\ 2 & 6.597 & \text { VV } & 0.375 & 62588035 & 5.800 & 6.765 \\ 3 & 7.477 & \text { VV } & 0.379 & 143937025 & 6.765 & 8.336 \\ 4 & 10.162 & \text { VV } & 0.341 & 1417052241 & 8.986 & 10.517 \\ 5 & 12.430 & \text { PB } & 0.217 & 85335911 & 11.04 & 12.778 \\ 6 & 13.863 & \text { BV } & 0.350 & 511804393 & 13.497 & 14.600 \\ 7 & 14.671 & \text { VV } & 0.074 & 35721285 & 14.600 & 14.904 \\ 8 & 15.046 & \text { VV } & 0.149 & 162348448 & 14.904 & 15.621 \\ 9 & 15.739 & \text { VV } & 0.167 & 7393385 & 15,621 & 16.476 \\ 10 & 16.538 & \text { VV } & 0.133 & 33866552 & 15.476 & 16.973\end{array}$

Fro. 12.-Capillary column GC-MS total ion chromatogram of R-830 reduced dichloromethane extract. 


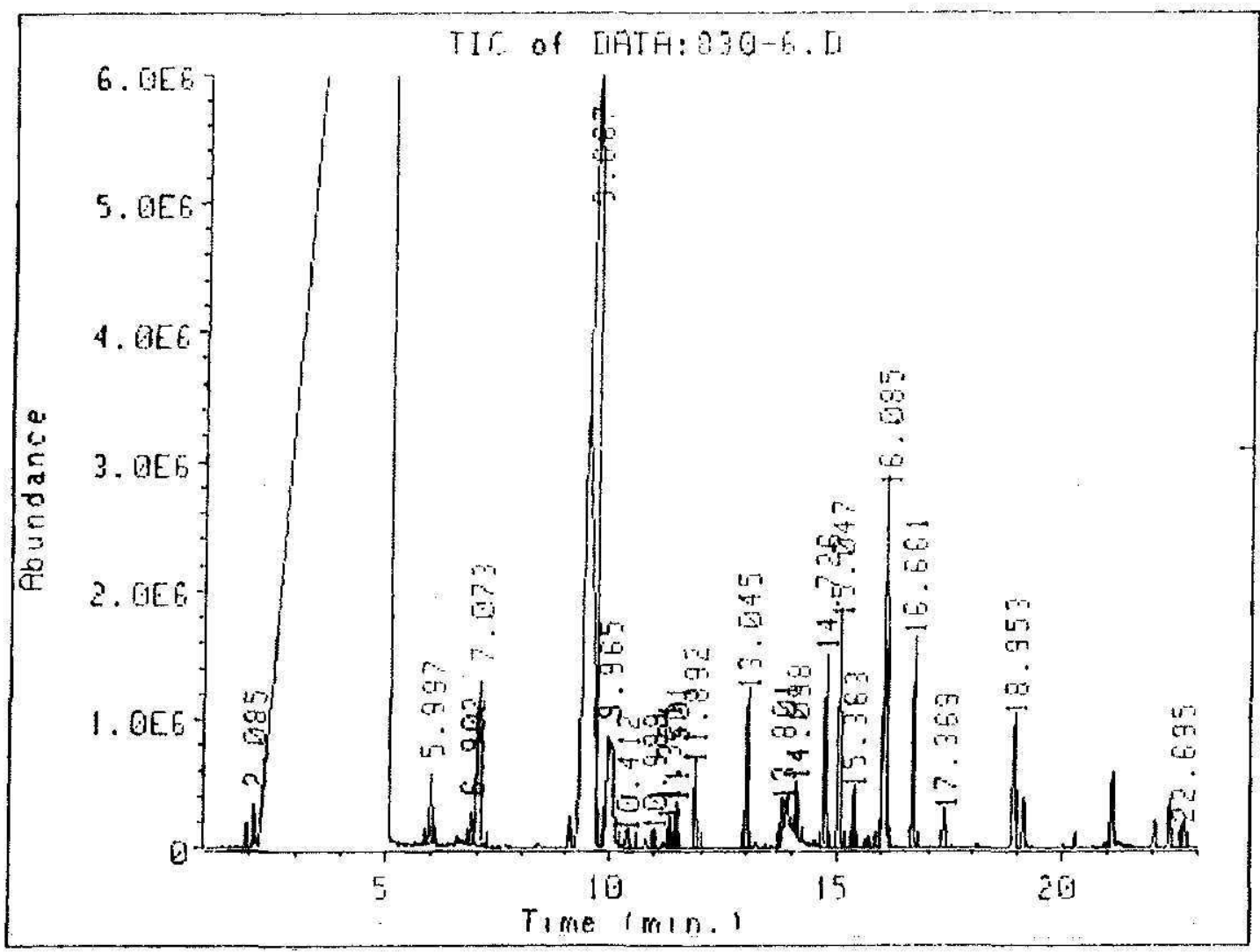

TIC of DATA:830-6.D

$\begin{array}{rrcrrrr}\text { Peak \# } & \text { Ret Time } & \text { Type } & \text { Width } & \text { Area } & \text { Start Time } & \text { End Time } \\ 1 & 2.085 & \text { VV } & 0.022 & 4001012 & 2.060 & 2.127 \\ 2 & 5.997 & \text { BV } & 0.060 & 20654212 & 5.839 & 6.079 \\ 3 & 6.902 & \text { BV } & 0.043 & 7259927 & 6.801 & 6.934 \\ 4 & 7.073 & \text { VB } & 0.073 & 65682477 & 6.934 & 7.228 \\ 5 & 9.667 & \text { BV } & 0.102 & 42658654 & 9.456 & 9.731 \\ 6 & 9.965 & \text { BBA } & 0.035 & 4938828 & 9.834 & 10.006 \\ 7 & 10.412 & \text { PB + } & 0.000 & 6107000 & 10.210 & 10.577 \\ 8 & 10.989 & \text { BH } & 0.031 & 2363177 & 10.928 & 11.017 \\ 9 & 11.321 & \text { PB } & 0.033 & 4997149 & 11.270 & 11.354 \\ 10 & 11.501 & \text { BH } & 0.035 & 8175542 & 11.436 & 11.540 \\ 11 & 11.892 & \text { BB } & 0.042 & 18803204 & 11.842 & 12.000 \\ 12 & 13.045 & \text { BH } & 0.050 & 39566821 & 13.943 & 13.114 \\ 13 & 13.801 & \text { PBA } & 0.077 & 11345822 & 13.740 & 13.867 \\ 14 & 13.098 & \text { BBA } & 0.027 & 6822127 & 14.057 & 14.235 \\ 15 & 14.726 & \text { PV } & 0.039 & 38421003 & 14.620 & 14.817 \\ 16 & 15.047 & \text { BV } & 0.051 & 58039990 & 14.951 & 15.156 \\ 17 & 13.363 & \text { BB } & 0.032 & 9276282 & 15.301 & 15.411 \\ 18 & 16085 & \text { BBA } & 0.061 & 44207966 & 15.941 & 16.099 \\ 19 & 16.661 & \text { BH } & 0.047 & 48325510 & 16.580 & 16.748 \\ 20 & 17.369 & \text { BH } & 0.046 & 9495155 & 17.268 & 17.419 \\ 21 & 18.953 & \text { BB } & 0.018 & 4576586 & 18.932 & 19.015 \\ 22 & 22.695 & \text { BB } & 0.056 & 8107223 & 22.639 & 22.783\end{array}$

Fig. 13.-Capillary column GC-MS total ion chromatogram of R-830 reduced dichloromethane extract. 
J. Agric. Univ. P.R. voL. 77, NO. 1-2, JANUARY/APRIL, 199389

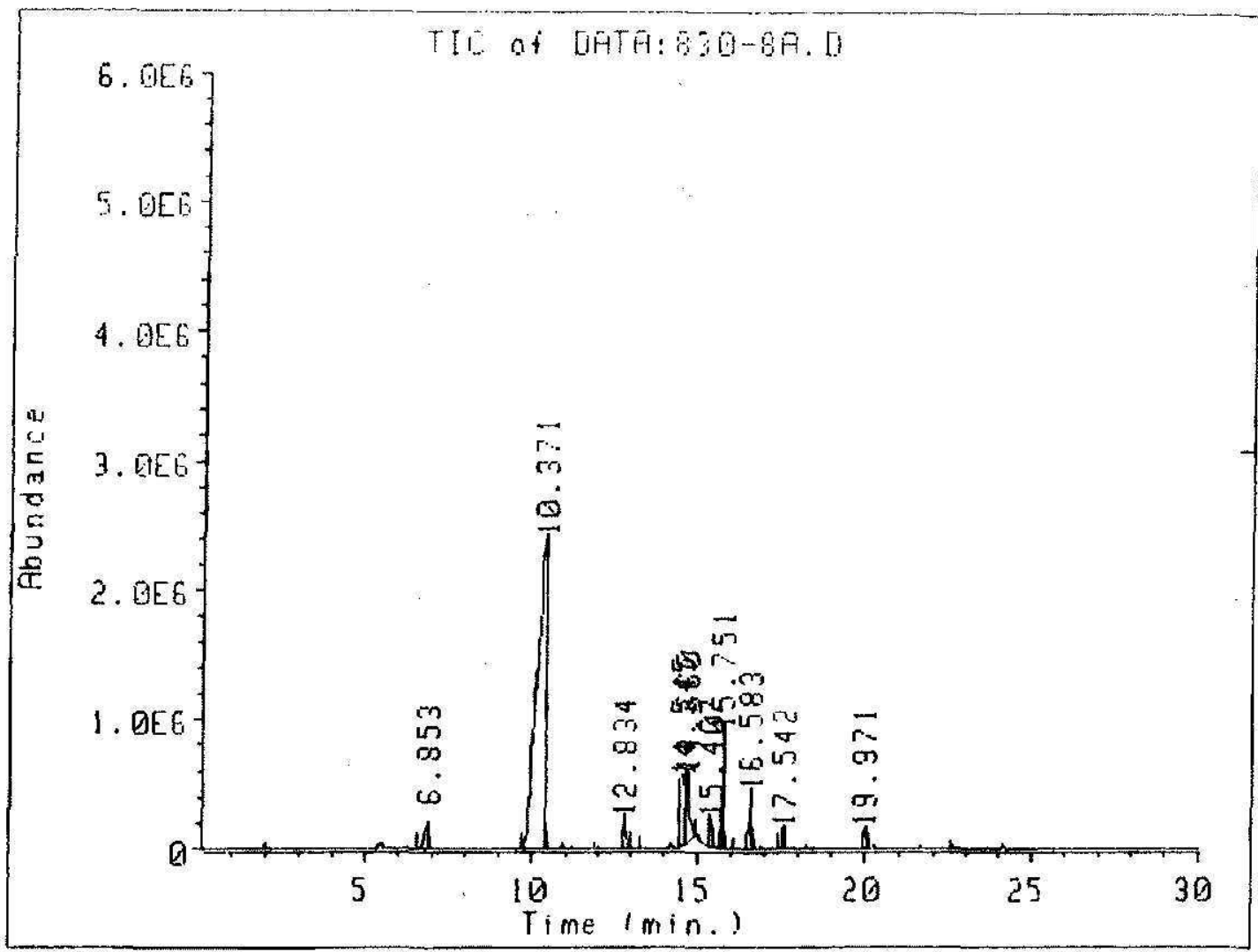

TIC of DATA:830-8A.D

$\begin{array}{rrlrrrr}\text { Peak * } & \text { Ret Time } & \text { Type } & \text { Width } & \text { Area } & \text { Start Time } & \text { End Time } \\ 1 & 6.853 & \text { BH } & 0.107 & 16179082 & 6.518 & 6.923 \\ 2 & 10.371 & \text { BH } & 0.239 & 4757811291 & 9.694 & 10.447 \\ 3 & 12.834 & \text { BH } & 0.071 & 13586039 & 12.778 & 13.019 \\ 4 & 14.545 & \text { BV } & 0.082 & 35240132 & 14.483 & 14.626 \\ 5 & 14.660 & \text { VV } & 0.095 & 40371454 & 14.626 & 14.931 \\ 6 & 15.407 & \text { BV } & 0.037 & 6367665 & 15.350 & 15.481 \\ 7 & 15.751 & \text { BB } & 0.058 & 40111437 & 15.627 & 15.833 \\ 8 & 16.583 & \text { BH } & 0.058 & 20063677 & 16.466 & 16.624 \\ 9 & 19.971 & \text { BB } & 0.069 & 7037315 & 19.891 & 20.068 \\ 10 & 19.971 & \text { BB } & 0.059 & 7037315 & 19.891 & 20.068\end{array}$

Fig. 14.-Capillary column GC-MS total ion chromatogram of R-830 reduced dichloromethane extract. 


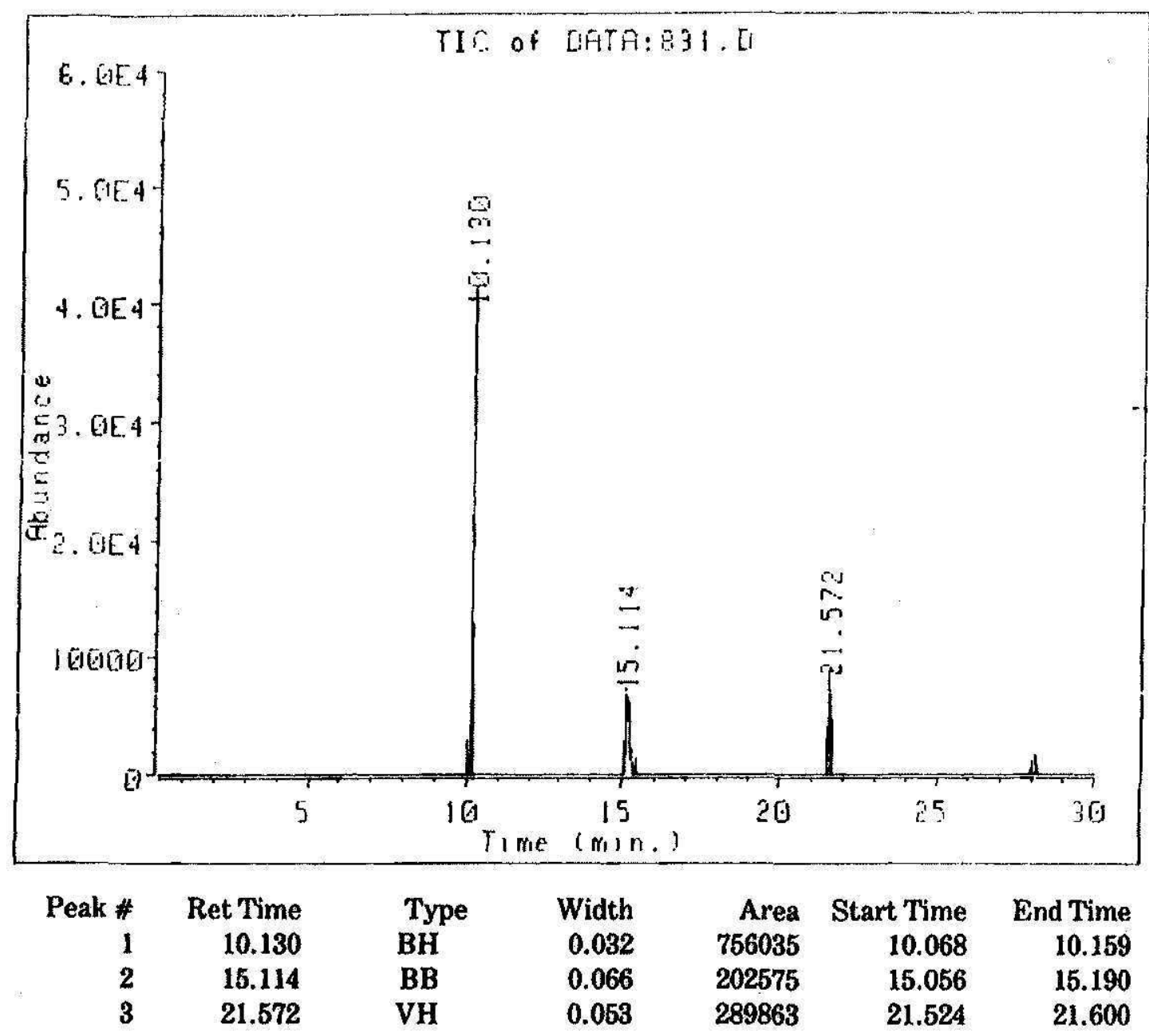

FrG. 15-Capillary column GC-MS total ion chromatogram of R-831 reduced dichloromethane extract.

to improve the correlation value, the concentration of the component in the sample must be increased to reach a greater difference between the signal noise and the corresponding component signal intensity. The present procedure resulted in about a 250 to 500 fold increase in the concentration of components, as compared with that of the neat sample, and the vast majority of components resolved with this technique are at concentration of $20 \mathrm{ppb}$ or less.

Although the technique was evaluated successfully and numerous components were separated in the different chromatograms, the extensive data are still being evaluated for future publications. Standard compounds must be acquired to make more positive GC-MS identification, especially of those compounds with probability values below $90 \%$. Moreover, compounds separated in the packed column system must be properly matched with appropriate standard to be able to validate the quantitative procedure. 


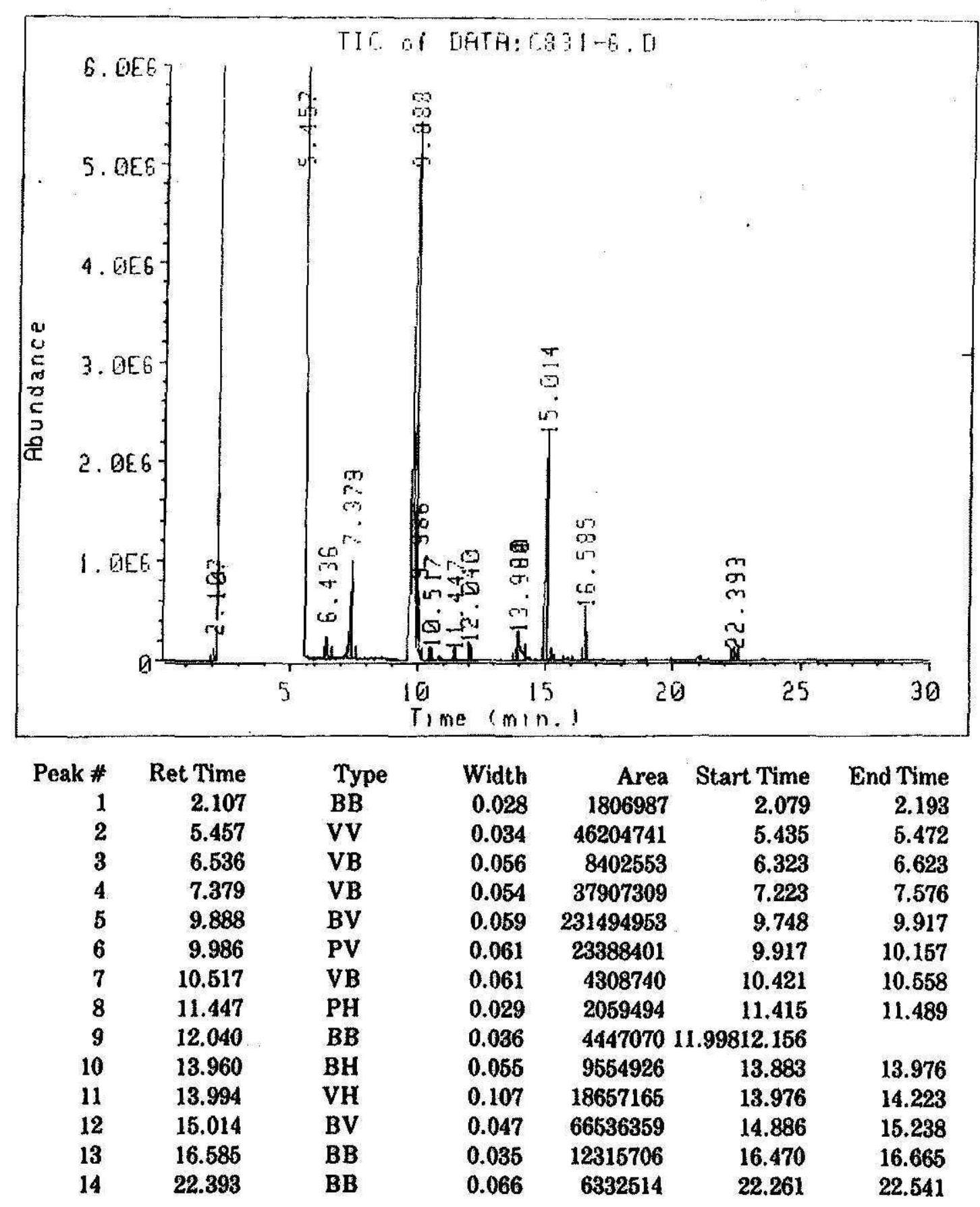

Frg. 16.-Capillary column GC-MS total ion chromatogram of R-831 reduced dichloromethane extract. 


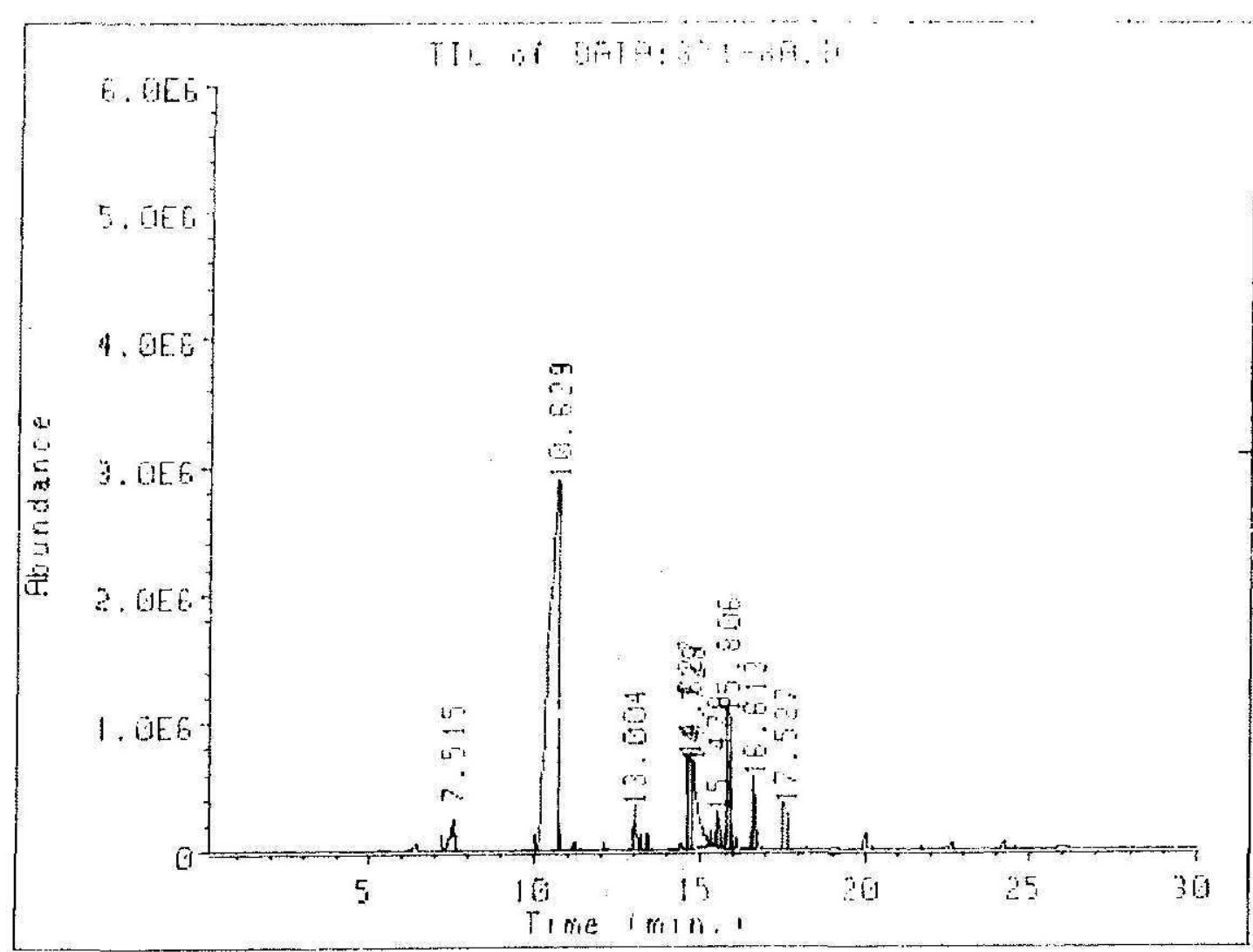

$\begin{array}{rrlrrrr}\text { Peak \# } & \text { Ret Time } & \text { Type } & \text { Width } & \text { Area } & \text { Start Time } & \text { End Time } \\ 1 & 7.515 & \text { BB } & 0.121 & 22935261 & 7.178 & 7.598 \\ 2 & 10.629 & \text { BH } & 0.244 & 571634724 & 9.994 & 10.724 \\ 3 & 13.004 & \text { BH } & 0.068 & 16722005 & 12.939 & 13.209 \\ 4 & 14.627 & \text { BV } & 0.070 & 3947491 & 14.589 & 14.700 \\ 5 & 14.728 & \text { VV } & 0.147 & 79296150 & 14.700 & 15.307 \\ 6 & 15.478 & \text { BB } & 0.039 & 7335849 & 15.407 & 15.577 \\ 7 & 15.806 & \text { BB } & 0.063 & 51084775 & 15.698 & 15.904 \\ 8 & 16.613 & \text { BV } & 0.052 & 21905187 & 16.488 & 16.665 \\ 9 & 17.527 & \text { BB } & 0.047 & 11820083 & 17.448 & 17.633\end{array}$

FIG. 17.-Capillary column GC-MS total ion chromatogram of R-831 reduced dichloromethane extract.

\section{LITERATURE CITED}

1. Batiz, H., 1979. Analysis of rums with a preparative-capillary system employing a newly developed trap-split. J. Agric. Univ. P.R. 63(4): 294-308.

2. - 1988. Preparative-analytical gas chromatographic techniques for mass spectrometric identification of rum composition. Proc. Sociedad Puertorriqueña Ciencias Agrícolas, Ponce, P.R., November (Abs).

3. - 1989. Preparative-analytical gas chromatography. Rum Pilot Plant, AEE-UPR, Río Piedras, Puerto Rico. Progress Report.

4. - 1991. Indirect preparative-gas chromatographic techniques for mass spectrometric identification of rum composition. J. Agric. Univ. P.R. 75(1): 51-60. 
5. Batiz, H. and E. Rosado, 1977. A trap-split unit for coupling preparative gas chromatography columns to analytical columns. J. Agric. Univ. P.R. 61(1): 108-12.

6. - 1979. A single column gas chromatographic method for the direct trace analysis of high boiling components in rums. J. Agric. Univ. P.R. 63(2): 380-42.

7. Batiz, H. and E. Soltero, 1976. Preparative-capillary gas chromatographic system for trace analysis of mum. J. Agric. Univ. P.R. 60(4): 559-84.

8. Brumley, W. C., B. J. Canas, B. A. Perfetti, M. M. Nossoba, and J. Sphon, 1988. Quantitation of ethyl carbamate in whiskey, sherry, port, and wine by gas chromatography tandem mass spectrometry using a triple quadrupole mass spectrometry. Analytical Chemistry, 60(10): 975-978.

9. Lehtonen, M. and Eriksson, 1983. P.J. volatile and non-volatile compounds in flavour of alcoholic beverages. Flavour of Distilled Beverages, Origin and Development. Ellis Horwood Limited, 64-78.

10. Lehtonen, $M$. and $P$. Lehtomen, 1986. The determination of volatile phenol in rum and brandy by GC and LC. Instrumental Analysis of Foods. 2, 397-407.

11. Liddie, P. and Bossard R., 1986. Glass capillary gas chromatography in the wine and spirit industry. Instrumental Analysis of Foods. Vol. 2, pp. 325.

12. Martin, G. E. and P. C. Buscami, 1981. Gas chromatographic determination of congeners in alcoholic products with confirmation by gas chromatography/mass spectrometry. Journal of the Association of Analytical Chemists, 64 (1) 6-190.

13. Nykänen, L. and I. Nykänen, 1983. Rum flavour. Flavour of Distilled Beverages, Origin and Development. Ellis Horwood Limited. 49-63.

14. Nykänen, L. and H. Suomalainen, 1983. Aroma of beer, wines, and distilled beverages, Akademic-Verlag, Berlin.

15. Piggott, J.R. 1983. Flavour of distilled beverages, origin and development. Ellis Horwood Limited. 276.

16. Rosado, E., H. Batiz, and M. Vilella, 1990. HPLC method for analysis of substrate and products in beverage alcohol production. J. Agric. Univ. P.R. 74(4) 357-364.

17. Simpkins, W. A., 1985. Congener profiles in the detection of illicit spirits, Australia Journal of the Science of Foods and Agriculture, 36 (5) 367-376.

18. Suomalainen, $H$. and $L$. Nykänen., 1966. The aroma components produced by yeast in nitrogen free-sugar solution. J. Inst. Brev., London, 72, 469-474. 